\title{
Beyond the Urge of Defense
}

\author{
MA Lin
}

Published online: 8 May 2008

(C) Springer Science + Business Media B.V. 2008

The debate surrounding the implication of two passages from the Mencius about Shun 舜, an ancient Chinese sage king, has been going on since 2002. The first time it drew my attention was when I obtained a copy of $A$ Collection of Contention on Confucian Ethics: The Case of Mutual Concealment of Father and Son (Guo 2004), which includes thirty-one articles by eighteen authors. I was quite impressed by the scholarly expertise of the two protagonists in this debate, namely, LIU Qingping and Guo Qiyong, as well as by the width and depth of the issues that are involved in this debate.

The central thesis Liu puts forward in a series of articles is two-fold: the ultimate moral basis of Confucianism is what he calls "consanguineous affection"; this principle has encouraged corruption as manifest in the two cases about Shun (Liu 2004, 2007). ${ }^{1}$ Guo's contention attempts to consider concrete contents of fraternal love and love between family members in general from a historical perspective. Contra Liu, Guo believes that "consanguineous affection" is the source of morality, and of "all positive value," rather than negative value (Guo 2004: 15). In the most recent article published in Dao, Guo opposes Liu's view that Confucian ethics is characterized by "consanguinism." He tries to highlight the importance Confucian ethics ascribes to the heart-mind and universal humanity, compared with which family love seems to be something derivative and particular (Guo 2007). Undeniably, Liu has invested a huge amount of intellectual endeavor in his work, which is manifest in the wide range of references to such Western thinkers as Habermas, Pascal, Kierkegaard, and Weber, and to prominent scholars on Chinese thought who publish mainly in English such as A. C. Graham, R. T. Ames, and B. Schwartz and D. Wong (see Liu 2006, 2007). However, he has paid less attention to situating his reading of the relevant passages about Shun in the immediate context of the Mencius.

\footnotetext{
${ }^{1}$ Liu does not always keep to his negative evaluation of Confucian family love. In the final conclusion of an article, with the assumption that "consanguineous affection" bears upon moral emotions, he remarks, "The emotional spirit of Confucius' philosophy may remedy the one-sided defects of Western rationalist philosophy" (Liu 2006: 185). Liu cites a statement of Ames to support this claim, which sounds to be something positive.
}

MA Lin $(\bowtie)$

School of Philosophy, Renmin University of China (Zhongguo Renmin Daxue), Beijing 100872, China e-mail: lin.ma.2007@gmail.com 
In reading the relevant texts carefully, it is clear that Mencius is not advocating blind loyalty to one's family members. In both cases, he has attempted to take into consideration both family love and social justice. In regard to the first story according to which Shun's father has committed murder, the first thing that occurs to Mencius' mind is that as a murderer, Shun's father should be arrested. It is when considering this case from the particularity of Shun's own position that Mencius suggests that Shun should give up his throne and flee together with his father to the border of the country. This suggestion has taken social justice into account inasmuch as the pre-condition for Shun to save his father is for him to resign his post as the emperor. Mencius is not upholding the principle of filial piety as an absolute code of behavior to the point of totally ignoring the principle of social justice. $^{2}$

Another story involves Shun's brother Xiang, who plotted to murder him. When Shun became emperor, instead of killing Xiang, he enfeoffed him. Mencius deliberately mentions that some people call this banishment. His analysis of Shun's decision again has taken into account both fraternal love and social and political justice. On the one hand, Shun manifests love for his brother in providing him a wealthy and respectful life; on the other hand, since the region where Xiang was banished was well under the control of Shun's central government, Xiang's power was effectively contained and hence social order and political order were well maintained. Therefore, it cannot be said that Shun treats fraternal love as something ultimate to which every other principle or consideration has to be subordinated. ${ }^{3}$

What Mencius is concerned with is how someone like Shun, who occupies a most prominent position, can make a balanced judgment when different commitments and principles come into conflict. It is not his intention to uphold filial piety and fraternal love as the supreme principle of conduct to the exclusion of any consideration of social justice. Taking these two cases to be primordial cases of corruption, Liu argues that "the Confucian spirit of consanguineous affection" has encouraged people to engage in corruption, which to Liu means that "universal principles" are sacrificed for the sake of family love (Liu 2007: 7). Liu is concerned with current social and political situations in China where cases of corruption occur and are reported one after another. However, a scholarly study of these cases involves expertise and training in such disciplines as sociology and jurisprudence. This does not mean that philosophy has no role to play. For example, a philosophical investigation of different notions of corruption in ancient and modern times can perhaps make a substantial contribution to a reflection on the origin and variety of corruption.

Guo's refutation of Liu's thesis has mainly focused on the question whether Shun's care about family love should be understood as a manifestation of moral concern or as unambiguous acts of corruption. In arguing for the first interpretation, Guo, like Liu, has taken into consideration social realities in China in recent decades, in particular the fact that, during the notorious Cultural Revolution from 1966-1976, normal human ethical relations were almost completely destroyed when people were encouraged to turn against their "evil" family members (Guo 2004: 14). Guo's familiarity with the history of Chinese philosophy is shown in the wide range of references to almost all the major Confucian thinkers from ancient times to the present era, such as CHENG Hao and CHENG Yi, LU Jiuyuan, WANG Yangming, Huang Zongxi, and Mou Zongsan. His discussions of the relevant texts from the Mencius seem to be more nuanced and convincing inasmuch as he

\footnotetext{
${ }^{2}$ According to Liu, justice resides in punishing criminals. However, punishment seems to be only one of the ways of preserving social order. Justice is a much broader social and political notion than punishment.

${ }^{3}$ In the earliest article that reads these two stories as cases of corruption, Liu has omitted the last passage (which says that Xiang's power was contained) in citing the second story (Liu 2004: 889).
} 
situates these stories in the particular historical and cultural context of Shun's dynasty and attempts to justify Shun's choice from his own perspective. While agreeing with Guo that it is unreasonable to cast the blame on Confucian morality alone for current prevalence of corruption in China, one must keep in mind that ancient Confucian moral teachings cannot be identified with absolute and immutable principles.

The phrase "mutual concealment of wrong doings among family members" (qin qin hu yin 亲亲互隐) comes from a story about Confucius: on hearing that in a certain state people describe someone as upright who reported to the authorities when his father stole a sheep, Confucius says: "among my people, those who we consider 'upright' are different: fathers cover up for their sons, and sons cover up for their fathers; 'Uprightness' is to be found in this" (The Analects 2003;13.18). I suggest that Confucius' statement be understood in connection with his idea of rectification of names, a relevant passage about which appears in the same chapter as this statement. His remark can be read as a hyperbolic statement: one's piety toward one's father can be so overwhelming that a son covers up his father's misdemeanors. What Confucius is primarily concerned about is that the ethical order of "fathers behaving as father; sons behaving as son" ( $f u f u z i z i$ 父父子子) should be maintained. That one should follow the practice of protecting one's family members from prosecution can be a practicable way of maintaining such an order. It assumes a secondary order and belongs to the realm of pragmatics. The relevant hyperbolic example is itself involved with a primary concern with social and political order.

Confucius and Mencius share a contingent existential aspect in their lives: as a toddler, both of them lost their fathers. If this dimension of personal life plays a role in their thinking, it would be quite understandable that the role of father holds a special attraction to them. This is especially the case with Mencius, whose suggestion implies that, personally speaking, Shun would prefer enjoying a harmonious life with his father at the seashore to remaining on the throne. An important difference between Confucius and Mencius in regard to their views concerning family relations resides in the following: with Confucius, the relations are presented as predominantly an institutional matter, that is, they are themselves an indispensable part of social and political order. Therefore, Confucius does not see the necessity of reconciling filial piety with social justice that is supposed to be something external to family relations. Social justice is partially embodied in family relations. When family relations are in harmony, social justice is done. With Mencius, the personal side of family relations comes to the fore. Mencius describes Shun's attachment to his parents vividly: Without love of his parents, he felt like a homeless person; only by getting into accord with them could his sorrows be dispelled, and this strong attachment to his parents remained even when Shun was fifty. From this difference between Confucius and Mencius it can be seen that there is not a homogeneous way of conceptualizing family relations in the Confucian tradition.

My interpretation of Confucius and Mencius' thoughts should not be taken to mean that I would advocate that we should accept their ideas without reservation and follow their suggestions in prima facie similar cases in the present age. Because of huge differences of social circumstances, it is impossible to transpose their way of thinking and reasoning into the contemporary world. What I want to stress is that it seems to be unsuitable to rely on current conceptions and mode of argumentation adopted from analytic philosophy to read ancient stories. For example, Liu argues that if all the criminals are protected by their respective families, then a society will be in chaos because of the potential harm of these uncaught criminals. As I have said, ancient Confucian moral teachings cannot be identified with absolute and immutable principles. One must understand them in relation to their particular concerns, instead of reading them as general codes of behavior. In addition, it 
does not seem to be the case that, ideally, if all the criminals are caught, a society will then be in perfect order, because it may turn out that there appear more criminals than the prison can imprison. In fashioning that argument, Liu presupposes the simplistic idea that criminals are just something evil that can be eliminated if they are thrown into jail. Although it can be stipulated in law that criminals should be punished, philosophical discussions of justice, punishment, and morality should be much more sophisticated than that.

A primary concern behind Guo's challenge of Liu's corruption thesis is that it may damage the image of the Confucian tradition and may mislead a great majority of people to discard it as worthless. For the sake of refutation, Guo seems to have been obliged to proceed with Liu's line of treating Confucianism as one unitary whole in order to justify it as a whole. In my view, the essence of philosophy involves conceptual determinations and differentiations and qualifying one's points accordingly. In this comment, I have attempted to employ this conception of philosophy in my discussion of Confucius' and Mencius' remarks. I believe that more avenues of philosophizing that build on sources and resources from classical Confucian writings will be opened up when philosophers do not have to work at the urge of defense. There might be more ways in which justice, which is not the same as justification, can be done to the multiple layers and levels of meanings and the variations of thoughts within the Confucian tradition.

\section{References}

The Analects. 2003. Edward Slingerland, trans. Indianapolis/Cambridge: Hackett Publishing.

Guo, Qiyong 郭齊勇, ed. 2004. Essays in the Debate on Mutual Concealment among Family Members in the Confucian Ethics 儒家倫理爭鳴集: 以 “親親互陰” 隱為中心. Wuhan 武漢: Hubei Jiaoyu Chubanshe. 2007. "Is Confucian Ethics a Consanguinism?" Dao 6: 21-37.

Liu, Qingping. 2004. "Virtue or Corruption?: An Analysis of Two Cases about Shun in the Mencius." In Guo (ed.) 2004.

2006. "On Confucius' Principle of Consanguineous Affection." Asian Philosophy 16 3: 173-188. 2007. "Confucianism and Corruption: An Analysis of Shun's Two Actions Described by Mencius."

Dao 6: 1-19. 